\title{
An Examination of the No Fail Policy in Thailand and the Effect on Community Relations
}

KRISTIN M. HALLIGAN

Assumption College, Thailand

Bio Data:

Kristin Halligan is currently finishing a Master's Degree in Multidisciplinary Science with a focus on International Education from the State University of New York. She is a second grade teacher at Assumption College Primary section in Bangkok, Thailand.

\begin{abstract}
No fail or social promotion policies have been implemented in many countries around the world over the last sixty years. Are these policies harmful or helpful in regard to academic achievement and well being of students? This article examines the trends of social promotion policy in the United States and Thailand. Research has been conducted at Assumption College Primary Section. Interviews and questionnaires were conducted and analyzed in order to observe opinions of educators, parents and teachers in regard to these policies.
\end{abstract}

Keywords: Social Promotion Policy, No Fail Policy, Retention, Not Meeting Standards

\section{Introduction}

\section{The USA}

Institutions and local governments around the world have been implementing no-fail policies in schools around the world for over 60 years. Some parents and educators believe that no fail policy de-motivates students and increases inherent laziness. They believe that if everyone can pass regardless of their marks, students have no incentive to excel. Parents 
in the United States go as far to think that their children will enjoy less success in life as a result of no fail policy. On the other hand, some educators and parents feel that " $F$ " grade and being held back have extremely negative effects on the students' motivation to learn. They also think that students will become de-motivated to learn if they receive bad grades. This paper will explore the positive and negative effects that no fail policies have on students, parents, educators, school communities and policy makers.

Social promotion policies came about in the 1950's in the United States, and were implemented throughout the 1950's and 1960's. These no fail policies were followed in the States for decades, teachers believing that the policies would improve the students' images of oneself and their attitudes towards school. The argument for social promotion practices at this time was that if students are given low marks and held back from moving to the next level, then drop-out rates will significantly increase. However, in the last few years in the United States retention policies are becoming more accepted. According to Bonner, (1999) "Retention is slightly preferred over social promotion."

In Memphis, the school system implemented social promotion policies much later than most places in the United States. The MPS started enforcing these policies in the late 1990's. The MPS has gone so far to abolish the giving grades in lower primary. This has caused an up-roar among the public sector. Thomas says "Why do away with grades? ... 
Maybe a report card full of Fs" is the wake- up call a parent needs (Roberts, 2009). Thomas goes on to say that even if the child has not mastered any of the subject matter, they will still be passed onto the next grade. In response to widespread opposition, the superintendant of the Memphis school altered his no fail-policy and implemented intensive study plans to prohibit young learners from failing including differentiated instruction methods. $76 \%$ of primary teachers completed a survey about whether they favored or opposed the no fail policy. The results showed that $61 \%$ of the teachers were in favor of this policy; however, they thought that they had not been properly trained to assist in differentiated instruction techniques that insure students' success (Roberts, 2009).

The following year in Memphis new changes were made to the no fail policy and the name of the policy was changed $t$ o the Not Meeting Standards policy as well. Students that had not completed the coursework were allowed to finish their assignments in the following semester. Some teachers believe that this policy creates a positive outlook on learning. Casey Jones says some students have come to her and stated, "I'm not meeting standards" (Roberts, 2010). Other educators vehemently oppose this policy and say that there is no incentive for trying to get a good grade. They believe this act may be creating a culture of failure. Parents are worried as well. They deem that these policies encourage their children to strive for mediocrity rather than excellence (Roberts, 2010). 
Parents in the United States are worried that their children will not be prepared to join the workforce after they have been corralled through the school system without putting forth the proper efforts. Tom Emens, a Cordova Elementary teacher says, "Parents are concerned their children are working more to mediocrity rather than exceeding standards and getting ready for the workforce" (Roberts, 2010). Harper (a leading motivational speaker and educator) states, "I worry that by building these weird academic environments where everybody passes and nobody gets an F, we prevent our kids from experiencing reality (2007). Educators, parents and the public community around the world are leaning towards getting rid of social promotion and no fail policies (Harper, 2007). Yet, educators still question if this is the correct course of action. Stevens, Tuck and Zimmerman ask "Is retention the answer? Have students in the past who were retained benefited from such a move? What happened to students who were socially promoted?" (2009).

\section{Thailand}

There are many aspects to examine when judging whether social promotion has positive or negative implications in Thailand. As previously stated social promotion was a trend in the United States dating back to the 1950's. Educators are currently pushing for retention policies to be implemented in most schools systems in the United States. According to the teachers at Assumption College Primary Section, this policy was put into practice about twenty years ago. If the pattern in Thailand follows the 
American plan then we could be teaching in an environment that follows a social promotion policy for at least forty more years with little regard to reteaching or differentiated instruction. The foreign teachers that I spoke with at Assumption College Primary Section mentioned that the students that do not pass each subject with at least a $60 \%$ grade must learn that subject at summer school for three days. The teachers do not believe that this is a sufficient amount of time to improve significantly. After the boys' have relearned the material for three days they are passed on to the next level regardless.

\section{School Profile}

Assumption College Primary Section is an all boys' school where the students are members of a higher socioeconomic class than the average Thai family. Assumption College Primary Section is a branch of more than 18 different schools spanning across all ages levels. The institutions have been governed by the Saint Gabriel Foundation since 1900. Assumption College has a reputation in Thailand for providing excellent academic environment and instilling good moral values in the attending students. The majority of the Thai teachers and administrators that were interviewed have been teaching at ACP for ten years or more. The foreign teachers do not stay at Assumption as long as the Thai nationals, simply because most foreign teachers go back to their home countries after living abroad for a few years. 


\section{Interviews and Questionnaires}

Social promotion strategies that the government and private institutions in Thailand currently follow are a fairly recent occurrence. The majority of the people that I interviewed, which included teachers and administrators at Assumption College Primary Section, informed me that this practice started around twenty years ago. I was finally able to obtain an exact year from the academic office at Assumption College Primary Section. The social promotion policy in Thailand was implemented in 1978. Before this, students that did not have a sufficient level of mastery were obligated to go to summer school for 21 weeks in order to achieve mastery of the subjects that they had failed. If the students did not possess sufficient mastery of a subject at the end of summer term, then they were held back to complete the grade level again. There were no limitations of how many years the children could be held back. Due to social pressures involved with being retained and having to redo the same grade again, the no fail policy was incorporated into the school system by the Ministry of Education of Thailand (Cadias, 2008).

I conducted interviews with three Thai parents that are teachers at Assumption College Primary section as well. One Thai teacher, who has worked at Assumption College Primary section for over 15 years, said that she is in favor of the no fail policy purely because of the financial aspects of being held back. This teacher is 42 years old and has a 12 year old son who attends ACP. Her main argument was that private school in Thailand is so 
expensive that parents cannot afford to have their children fail. I spoke with another Thai teacher and parent, who is 45 years old, and has a son that is 14 years old. His son attends Assumption Matayom. This teacher said he does not agree with social promotion because he believes that the students are much lazier now than they were when this policy did not exist in Thailand. He also mentioned that literacy rates were much higher in Thailand before the no fail policy was implemented. This teacher has also been with ACP for 18 years. A third teacher- parent that I spoke with said that she thinks that social promotion is acceptable in order to ensure the psychological well being of the students. This teacher is 32 years old and has worked at Assumption College Primary Section for 7 years. She has a daughter that is not school age as of now. All three teachers did not agree with the current policy of three day summer school. They alleged that students who have not mastered subject content should re-learn the entire summer term and then re-test.

I also interviewed one foreign teacher at Assumption College Primary Section that is also a parent. He is a white male, 36 years old, from America who has been teaching at Assumption College Primary Section for five years. He has two children, a son who attends ACP, and a daughter who is not school age. He does not believe in social promotion policy but did talk of the importance of differentiated learning methods to ensure that every student is able to succeed. He became quite animated and seemed a bit angry about the no fail policy. He also believed that every student that 
does not possess sufficient mastery should be taught over the summer term to ensure future successes. He informed me that five years ago there was not even a policy where students had to re-learn at all over the summer session.

I created a ten question questionnaire based on a five point Likert scale. The statements addressed the issues of parents' opinions about no fail policy, students' motivation levels and social well-being and teachers' motivation to teach in regards to the no fail policy. The questions were all written positively to accurately gauge the results. The questionnaire was completed by twelve Thai teachers and twelve foreign teachers. The results of the two sample groups varied significantly. The average value of Thai teachers was thirty eight points out of a possible fifty points. The foreign teachers had an average of thirty two points. The foreign teachers' values increased according to the increase of the number of years that they have taught in Thailand.

\section{Data Analysis}

The interviews and questionnaires suggest that foreign teachers do not support no-fail policies to the same extent as the Thai teachers. As previously stated, the Thai teachers scored a full six points higher than the foreign teachers. There were some similarities in the two group's questionnaires. Both Thai teachers and foreign teachers, alike chose either four or five (partially agree and strongly agree) in response to the statement, students are de-motivated to learn if they receive an " $f$ " or a failing 
grade. The previous research that I conducted (studies from the United States) pertaining to failing marks and motivation to learn did not agree with this statement. The articles that were examined pointed out that " $\mathrm{f}$ " grades do not necessarily harm students' motivation to succeed. Low marks may even motivate students to work harder in their studies.

One discrepancy between the foreign and Thai teachers was that Thai teachers responded to the statement, it is okay to change grades in order to help low achieving students, with fours and fives. The foreign teachers, with the exception of two people, responded to this statement with twos (strongly disagree). This can be attributed to the social climate of Thailand where "helping" students is much more prevalent and accepted than in the west.

One thing that I found interesting while conducting my research is that none of the Thai parents seemed worried about their children's future in accordance with social promotion policy. The interviewees did not seem concerned at all that their children would be unaccustomed to failure that exists in real life situations when their children go to University or join the workforce whereas this thought was a common theme in the articles that I researched for this essay.

\section{Conclusion}

There are many arguments for and against social promotion policies that are still followed in many parts of the world. Educators, parents, students and policy makers have varied opinions about the benefits of no fail 
policies. However, most educators (Harper, 2007) agree that there should be some system of holding back students until they are able to achieve an adequate level of mastery. More in-depth case studies should be performed on students to assess the negative and positive aspects of social promotion policy. "What a great preparation for the realities of life beyond school this kind of learning environment would be. What are we teaching our kids when the message is that... not studying, not paying attention in class, not completing homework and not being a responsible, diligent student... has no real downside? (Harper, 2007).

\section{References}

Bronner, E. (1999, January). Social promotion is bad: Repeating a grade may be worse. The New York Times on the Web. Retrieved March 17, 2011, from http:/ / searchnytimes.com/search/da

Cadias, A. (2008, May). Breaking the controversies behind Thailand's no-fail policy. Retrieved March 20, 2011, from http:/ / abelcadias.blog.co.uk

Harper, C. (2007, March). Grooming our kids for failure. Retrieved March 20, 2011, from http:/ / buzzle.com

Roberts, J. (2009, September). Parents seek answers on MCS no-fail plan. The Commercial Appeal.

Roberts, J. (2010, November). Memphis city school teachers reject no-fail policy. The Commercial Appeal. 
Stevens, J., Tuck, L. \& Zimmerman, F. (1999). Issues challenging education: one more time: The social promotion debate. Horizon Site on the Web. Retrieved March 19, 2011, from http:// horizon.unc.edu

\section{Appendix 1}

Rate the following statements according to your opinion about the items.

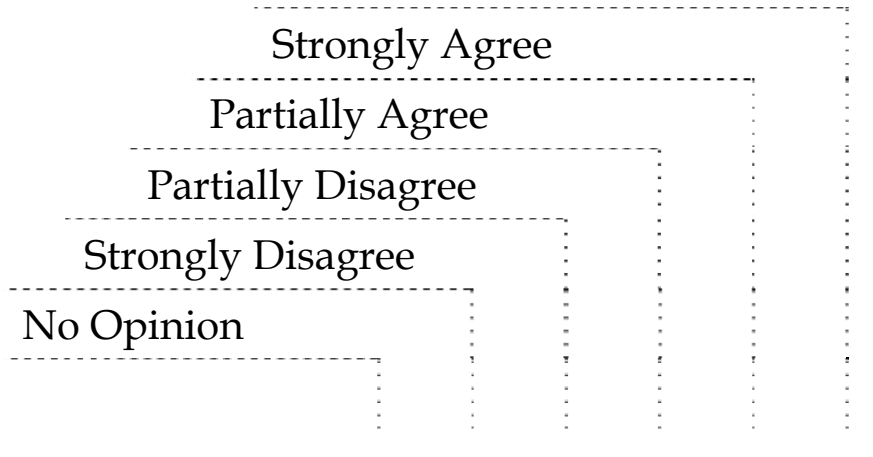

1. Students should advance to the next level $\begin{array}{lllll}1 & 2 & 3 & 4 & 5\end{array}$ even if their mastery of the subject matter is insufficient.

2. Students feel shy if they are held back $\begin{array}{lllll}1 & 2 & 3 & 4 & 5\end{array}$ with children that are younger than them.

3. It is okay to change grades in order to help low achieving students.

4. Students are de-motivated to learn if they receive an " $F$ " or failing grade.

5. Parents at our school support the no fail policy.

6. I believe that no fail policies are good for $\begin{array}{lllll}1 & 2 & 3 & 4 & 5\end{array}$ the well being of the students.

7. Students at my school try their best 
regardless of no fail policy.

8. I feel motivated to teach the children to $\begin{array}{lllll}1 & 2 & 3 & 4 & 5\end{array}$ the best of my ability every day regardless of no fail policy.

9. Students at my school will be successful members of the workforce in the future regardless of no fail policy.

10. The teachers at my school are motivated $\begin{array}{lllll}1 & 2 & 3 & 4 & 5\end{array}$ to teach the children every day regardless of no fail policy.

What grade level do you teach?

What nationality are you?

\section{Appendix 2}

1. Do you agree or disagree with Assumption's no fail policy?

2. What are your reasons for this?

3. Do you think that the parents of Assumption College primary section agree with social promotion policy and why?

4. How many children do you have?

5. How old are they?

6. How long have you worked at Assumption? 